

UDC 622.831 .325

https://doi.org/10.33271/mining13.01.086

\title{
APPLYING EUROPEAN APPROACH TO PREDICT COAL SELF-HEATING IN UKRAINIAN MINES
}

\author{
Yu. Gamiy $^{1 *}$, Ya. Liashok ${ }^{2}$, V. Kostenko ${ }^{2}$, O. Zavialova ${ }^{2}$, T. Kostenko ${ }^{3}$, O. Kostyrka ${ }^{3}$ \\ ${ }^{1}$ State Militarized Mine-Rescue Service, Myrnohrad, Ukraine \\ ${ }^{2}$ Donetsk National Technical University, Pokrovsk, Ukraine \\ ${ }^{3}$ Cherkasy Institute of Fire Safety named after Chornobyl Heroes of National University of Civil Defense of Ukraine, Cherkasy, Ukraine \\ *Corresponding author: e-mail gamiyyv@gmail.com,tel.+380500469222
}

\begin{abstract}
Purpose is the prediction of coal self-heating and determination of the factors effecting the dynamics of emission of tracer gases (TG) used for routine control of coal self-heating within the production unit involving European approach.

Methods. To determine the composition of mine ventilation flows, mine air was sampled into a rubber chambers with the volume of 1 liter; after that, gas content (\%) was determined in State Militarized Mine-Rescue Service (SMMRS) gas analytical laboratory with the help of "SIGMA-SO-V" and "Kristall" gas analyzers. Arrangement of sampling points is specified according to the normative document. Sampling periodicity while identifying a threat of coal self-heating within the worked-out area was three hours; in terms of standard conditions, the periodicity was not less than once a day. Period of monitoring within the mine working areas is not less than $9-10$ days. Experimental observations were performed in terms of the production unit of "Pioner" mine and "Pokrovske" mine office.

Findings. Innovative approach to routine control of coal self-heating taking into consideration TG dynamics has been tested in terms of the pillar system with return-flow ventilation of a mine section. It has been defined that within the area of expected place of coal self-heating, carbon oxide (CO) consumption within the mine workings was up to $20.59 \mathrm{l} / \mathrm{min}$, and the worked-out area was the source of TG emission; if there were no signs of self-heating, selfheating was not more than $4-6 \mathrm{l} / \mathrm{min}$. It has been determined that the TG emission nature is effected by geological (coal grade, seam occurrence, and seam disturbance) and technological (development system, ventilation scheme, rate of stoping advance, downtime periods etc.) factors.
\end{abstract}

Originality. It is for the first time when, in terms of mining-geological and mining-technical conditions of Donbas, the factors, determining dynamics of tracer gases within the production unit in terms of pillar system of seam development, have been defined.

Practical implications. Possibility to use European methodology of routine control of coal self-heating in Ukrainian mines has been substantiated and validated.

Keywords: endogenous fire, coal self-heating, tracer gases, ventilation flow, thermal destruction of coal

\section{INTRODUCTION}

According to the data by the Ministry of Power and Coal Industry, extraction of steam and coking coals in Ukraine in 2015 decreased by 1.6 times due to the military operations in Donbas comparing to 2014 (from 65 down to $39.759 \mathrm{mln} \mathrm{t}$ ). About $25 \%$ of coal is mined by state enterprises while about $75 \%$ is extracted by private enterprises (tenant-operated or conceded ones) though a share of the latter is only $40 \%$ of the total number of mines (Yashchenko, 2017). Recently, a situation with the provision of Ukraine with its own energy carriers has deteriorated due to the blockade of coal supply from the uncontrolled territories.
In the context of coal deficiency, underground accidents complicate considerably mining operations, resulting in the loss of coal reserves prepared for extraction, costly coal-mining facilities, and reduced national energy security. Particular damage is caused by endogenous fires being the results of spontaneous coal combustion; the fires occur in hard-to-reach places that complicates their detection at early stage as well as makes it harder to localize and suppress them. Lack of exact data on fire location reduces sharply the efficiency of fireextinguishing and application of cooling agents; thus, to fight the fire, mostly isolation technique is used. Within the period of $2015-2017$, there were 10 underground

(C) 2019. Yu. Gamiy, Ya. Liashok, V. Kostenko, O. Zavialova, T. Kostenko, O. Kostyrka. Published by the Dnipro University of Technology on behalf of Mining of Mineral Deposits. This is an Open Access article distributed under the terms of the Creative Commons Attribution License (http://creativecommons.org/licenses/by/4.0/),

which permits unrestricted reuse, distribution, and reproduction in any medium, provided the original work is properly cited. 
fires at all the coal-mining enterprises; total length of mine workings isolated due to those fires was: 2015 $15533 \mathrm{~m}, 2016-22067 \mathrm{~m}$, and $2017-22084 \mathrm{~m}$.

The situation is complicated by the fact that the equipment and laboratory facilities aimed at controlling and predicting coal self-heating processes are now at the territory being beyond the control of Ukraine. Thus, currently, Ukrainian mines are not provided with the means to prevent and detect fires caused by coal selfheating at early stages. Moreover, seams are not classified according to the danger of spontaneous combustion basing upon the laboratory evaluation of their chemical and physical properties. There is also much concern about providing extraction sites in mine working areas developing coal seams prone to spontaneous combustion with modern fire-control facilities.

Coal fires are a serious problem in numerous coalmining countries (e.g. the USA and China) being the result of worldwide environmental and economic problems (Stracher \& Taylor, 2004). In this context, European experience in monitoring atmosphere composition within production units to detect early stages of coal self-heating is of high interest. It is based on well-known facts that the process of thermal destruction of coal is accompanied by the emission of a range of gaseous products into the atmosphere. Certain share of those products is nonavailable in standard mine air; they are little prone to sorption on coals and rocks and poorly water-soluble, so they may act as indicators in the process of coal self-heating. Last century, mining science determined carbon oxide $(\mathrm{CO})$ and hydrogen $\left(\mathrm{H}_{2}\right)$ as the most informative tracer gases characterizing the development of coal self-heating process.

\section{ANALYSIS OF CURRENT STUDIES}

Nowadays, miners and scientists in Check Republic and Poland use mine methods of control in terms of tracer gases dynamics (Feng \& Adamus, 2014). The method is characterized by the interferences stipulated by TG emission during mechanical destruction of coal by rock pressure and mining machines, air-flow vibrations, and other reasons determining the availability of certain tracer gases background in the mine air. Owing to that, control of TG dynamics is supplemented by laboratory evaluation of the temperature in coal accumulation relative to the unsaturated hydrocarbons (Rukovodstvo po preduprezhdeniyu..., 2000; Pashkovskiy, 2013). Determining the degree of self-heating which may be defined by analyzing gas composition is one of the widely used techniques to predict coal self-heating (Hu, Yang, Zhou, $\mathrm{Yu}, \& \mathrm{Hu}, 2015)$. Carbon oxide is considered as the basic tracer gas as it is generated at low temperature and has higher concentration than other constituent gases; besides, carbon oxide is easy to control (Zhuang \& Ji-Ren, 2011).

Currently, numerous scientific institutions in the European Union, the USA, China and other foreign countries are involved into the development of the method to detect endogenous fires according to TG dynamics (Trenchek, 2017; Zhu, Chang, \& Wang, 2017). For instance, a scientific work by S. Trenchek (Trenchek, 2017) deals with the detalization of the method to evaluate the development of coal self-heating place according to TG dynamics in terms of pillar coal-seam mining.
The detalization means that basing upon the volume of carbon oxide emitted within the production unit $\left(V_{\mathrm{CO}}\right.$, $1 / \mathrm{min}$ ) and its increment, three basic stages of the development of a self-heating place were singled out. Stage one, in terms of $0 \leq V_{\mathrm{CO}} \leq 10$ and $0 \leq \Delta \mathrm{CO} \leq 0.0026$, shows the evolution of the threat of coal self-heating and necessity to increase the frequency of TG measurements in the air composition. Stage two, $10 \leq V_{\mathrm{CO}} \leq 25$ and $\Delta \mathrm{CO} \leq 0.0026$, makes it possible to continue stoping operations while taking measures to localize self-heating process and other preventive actions. That stage tells about the development of coal self-heating process within the accumulation when critical temperature of its spontaneous combustion is not reached (Regulation of the Minister..., 2017; Trenchek, 2017). If $\Delta C O \geq 0.0026$ or $V_{\mathrm{CO}} \geq 25$, it is required to perform a complex of fire protection activities.

The methodology is characterized by certain complexity, quantitative indices should be calculated for return ventilation air taking into account the difference in concentrations between the return and intake ventilation air flows (Fig. 1).

(a)



(b)

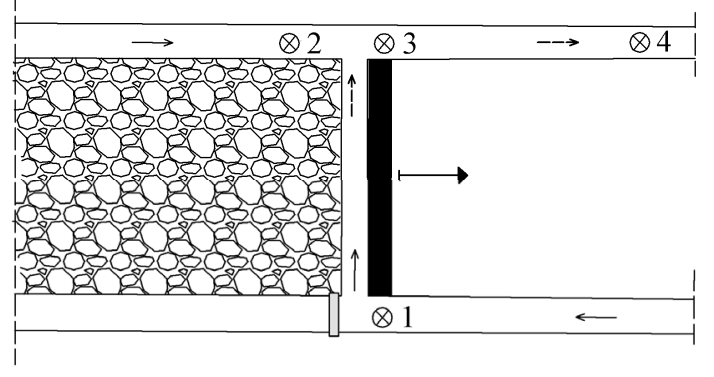

(c)

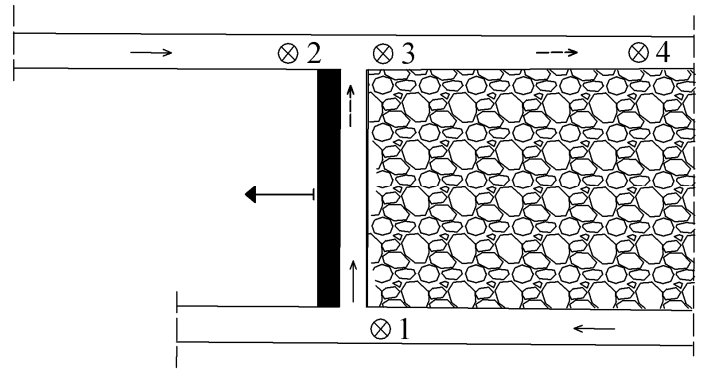

Figure 1. Scheme of the arrangement of gas sampling points in terms of return-flow ventilation scheme (a) and refreshing of return air onto the coal mass (b) and worked-out area (c): $\bigotimes_{- \text {gas }}$ sampling point; $\longrightarrow$-fresh air; $\longrightarrow-$ return air 
If, for instance, extraction unit (Fig. 1) is ventilated in terms of return-flow ventilation scheme and air consumption in the income air is $1000 \mathrm{~m}^{3} / \mathrm{min}$, with $\mathrm{CO}$ content being $0.0003 \%$, and worked-out area emits $0.0024 \%$ of CO, then concentration within the return air will be equal to $0.0027 \%$. That indicates the available fire, but $\mathrm{CO}$ concentration within the worked-out area being $0.0024 \%$ tells about the nonavailability of spontaneous coal combustion.

A model of the prognosis developed in China was based on the processing of reference vectors where numerous applications were used such as problem of recognition and defect of diagnostics with high dimension and nonlinearity. Importance of accurate prediction of coal self-heating on mine seams cannot be underestimated for coal mining safety (Oliveira, 2012; Kronbauer, 2013; Ribeiro, Taffarel, Sampaio, Flores, \& Silva, 2013; Martinello, 2014).

However, use of European methodology for routine coal self-heating control in Ukrainian mines is complicated due to the inconsistencies between safety requirements in the European Union and Ukraine.

According to the requirements of the Rules of safety in coal mines of Ukraine (NPAOP 10.0-1.01-10, 2010), maximum $\mathrm{CO}$ concentration in the air of working zones is $0.0017 \%$ being much lower limit than at the similar coal enterprises of other countries. Document \#ID-210 by the Occupational Health and Safety Administration of the USA (OHSA) shows that admissible CO concentration at the working place is $35 \mathrm{ppm}$ being equal to $0.0035 \%$ (OSHA Method ID-210, 1991). In its document \#1118 of 09.06.2017, Ministry of Energy of Poland states that boundary admissible content of carbon oxide is 0.0026\% (Regulation of the Minister..., 2017) while Rules of Safety for Coal Mines of China indicates that boundary admissible CO content in the mine air is $0.0024 \%$.

In Ukraine, when boundary admissible level at working places is $\mathrm{CO}=0.0017 \%$, then mining operations should be stopped up to the recovery of normal ventilation. Thus, it is inadmissible to use European methodology without introducing any changes. Use of Ukrainian norms in it as the criteria may result in incorrect performance of accident-prevention technical operations.

Routine controlling of coal self-heating as for emission of such TG as carbon oxide in the production unit air of the Ukrainian mines is a topical subject for further studies.

\section{RESEARCH METHODOLOGY}

In the context of Ukraine, there is a methodology to control early signs of spontaneous coal combustion; it is based on the organization of laboratory control over early signs of spontaneous coal combustion and techniques to determine fire-prone areas (Rukovodstvo po preduprezhdeniyu..., 2000). However, all the laboratory, documentary, and methodological bases are at the territory being beyond the control of Ukraine. The paper involves the approach basing upon technical means of SMMRS laboratories.

Methodology to study carbon oxide content stipulates mine air sampling within the mine workings in terms of return and intake ventilation air as well as in pipelines of isolated methane drainage, degassing pipelines and wells. In this context, consumption of gas flows within the sampling points was measured with the help of anemometers and diaphragms.

Such a procedure was used to record the effect of changes in mining-geological and mining-technical situation upon generation of tracer gases within certain production unit of a mine.

Mine air was sampled into rubber chambers with the volume of 1 liter; after that, gas content (\%) was determined in SMMRS gas analytical laboratory with the help of "SIGMA-SO-V" and "Kristall" gas analyzers. Arrangement of sampling points is specified according to the normative document (Rukovodstvo po preduprezhdeniyu..., 2000) (Fig. 1).

Sampling periodicity while identifying a threat of coal self-heating within the worked-out area was three hours; in terms of standard conditions, the periodicity was not less than once a day. Maximum sampling frequency is explained by the fact that the mechanism of TG emission in terms of different types of stoping operations (coal getting, support advancing, maintenance and repair activities) was unknown. Period of monitoring within the production units was not less than $9-10$ days so that main roof squeezing would take place during that period that would also effect gas emission from the worked-out area.

Experimental part of the observations was performed in production units of "Pioner" mine in the $3^{\text {rd }}$ northern longwall of $\mathrm{m}_{4}^{2}$ seam of $500 \mathrm{~m}$ level and in "Pokrovske" mine office in the $12^{\text {th }}$ southern longwall of block 10 of $\mathrm{d}_{4}$ seam. Figure 2 and 3 demonstrate sampling points in extraction units and type of analyzed gases.

Figure 2 shows ventilation scheme of the site of $1 \mathrm{M}-\mathrm{N}-\mathrm{v}-\mathrm{vt}$ type according to normative document (Rukovodstvo po proektirovaniyu..., 1994). Worked-out area was degassed by "vents" with the help of underground degassing plant (PDU-50-2).

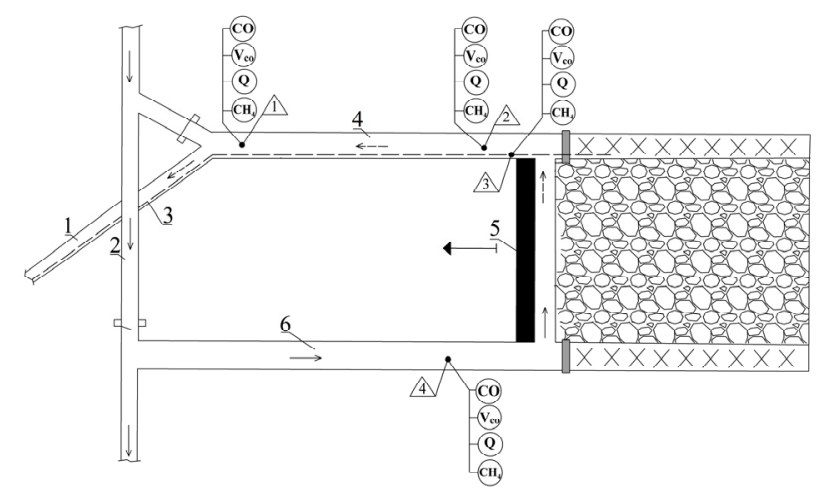

Figure 2. Ventilation scheme of the 3rd northern longwall of $\mathrm{m}_{4}{ }^{2}$ seam of $500 \mathrm{~m}$ level of "Pioner" mine: $\Delta$-sampling points and types of the analyzed gas; 1 - inclined crosscut \#46; 2 - dipping drift; 3 - pipeline of PDU-50-20 degassing plant; 4 - air drift; 5-the $3^{\text {rd }}$ northern longwall of $\mathrm{m}_{4}^{2}$ seam; 6 - belt entry

Figure 3 represents ventilation scheme of the $14^{\text {rd }}$ southern longwall of block 10 "Pokrovske" mine office. Fresh air is supplied through the $14^{\text {rd }}$ southern belt entry with return air supply onto the $12^{\text {th }}$ southern belt entry. 


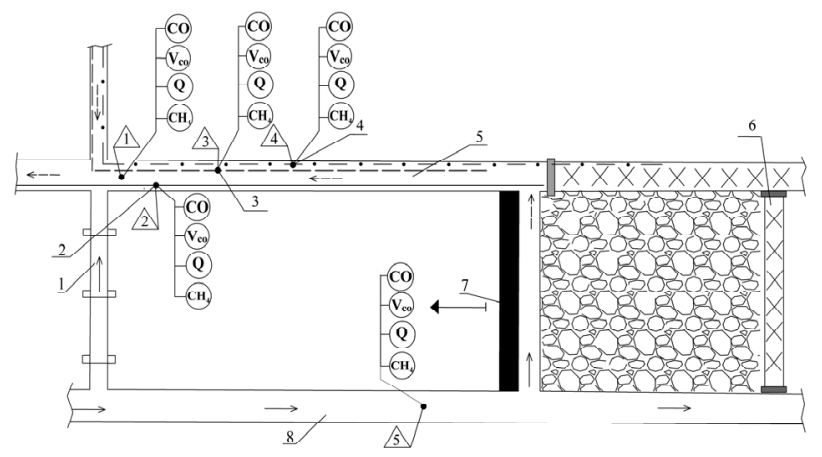

Figure 3. Ventilation scheme of the $14^{\text {rd }}$ southern longwall of block 10 of "Pokrovske" mine office: 4 - sampling points and types of the analyzed gas; 1 -ventilation connection of the $14^{\text {th }}$ southern longwall; 2 - pipeline of isolated methane drainage by VMTsH-7M ventilator; 3, 4-pipeline of PDU-50-20 degassing columns of $0426 \mathrm{~mm}$ and $0325 \mathrm{~mm}$ correspondingly; $5-13^{\text {th }}$ southern belt entry; 6 - mounting manway of the $14^{\text {th }}$ southern longwall; 7 -the $14^{\text {th }}$ southern longwall; 8 - the $14^{\text {th }}$ southern belt entry

\section{MINING-GEOLOGICAL AND MINING-TECHNICAL CONDITIONS OF THE AREAS UNDER STUDY}

"Pioner" mine belongs to the $3^{\text {rd }}$ gas hazard category being dangerous in coal-dust explosion and safe in coal and gas outbursts. The coal is not prone of spontaneous combustion. Maximum mining depth is $690 \mathrm{~m}$. Natural methane content of $\mathrm{m}_{4}{ }^{2}$ seam is $4.5-6.5 \mathrm{~m}^{3} / \mathrm{t}$.c.m. Absolute methane content in a mine is $6.1 \mathrm{~m}^{3} / \mathrm{min}$, relative methane content is $11.1 \mathrm{~m}^{3} / \mathrm{t}$ per day output. Maximum temperature of enclosing rocks is $25^{\circ} \mathrm{C}$.

The mine applies panel development layout; mining method is represented by long-pillar $(900-1530 \mathrm{~m})$ working along the strike; stoping lengths are $300 \mathrm{~m}$. Mine workings are ventilated by ventilation plants (VOD-18, VTs-32) located within the main shaft and ventilation hole on $l_{3}$ seam. Ventilation scheme is of suction type.

The $3^{\text {rd }}$ northern longwall of $500 \mathrm{~m}$ level of $\mathrm{m}_{4}^{2}$ seam is equipped with 1MKDD powered system, 1KDD and 3KD-90 supports, SP-251 conveyor, and UKD-200-400 shearer. Roof control is implemented by complete caving. Rock mass is transported from the longwall by SP-251.13 scraper conveyor, 1LT-1000 belt conveyor with reloading onto $3 \mathrm{~L}-1000$ main belt.

KSP-32 combined machine was used to drive opening and developing mine workings. Air drift is fixed with flexible archs of AP-13.8 type. Spacing for support frames is $0.8 \mathrm{~m}$. Roof and walls are lagged tightly with cyclone fencing. Support of belt entry is KShPU-15.0. Spacing of frame mounting is $0.8 \mathrm{~m}$. Roof and walls are lagged tightly with cyclone fencing.

Average thickness of the seam is $1.05 \mathrm{~m}$; seam dip is $14^{\circ}$. In the beginning of the development of extraction pillar of the $3^{\text {rd }}$ northern longwall, the coal seam was represented by one coal ply. Argillite with the thickness up to $5.3 \mathrm{~m}$ occurred immediately in the seam roof; upper, there was a coal interlayer with the thickness of $0.10-0.20 \mathrm{~m}$, and further there was sandstone of $1.0-3.4 \mathrm{~m}$ thick. Along with the pillar development, thickness of argillite of the immediate roof decreased down to $0.4-0.63 \mathrm{~m}$. At the same time, thickness of coal interlayer increased up to $0.4 \mathrm{~m}$ (Fig. 4). That situation should be considered as sedimentary geological disturbance which could provoke coal self-heating within the interlayer.

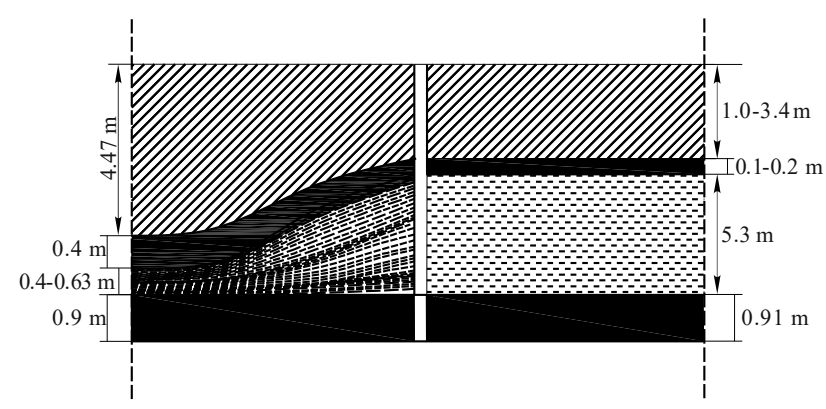

Figure 4. Stratigraphy of the roof of the $3^{\text {rd }}$ northern longwall of $\mathrm{m}_{4}{ }^{2}$ seam of $500 \mathrm{~m}$ level of "Pioner" mine: (a) changes in coal interlayer while developing extraction pillar; (b) coal interlayer at the beginning of the extraction pillar development

In "Pokrovske" mine office, the $14^{\text {th }}$ southern longwall of the $10^{\text {th }}$ block is located in the south-west of the mine field. Interrelation of stoping advance rate and tracer gas emission has been evaluated. Seam $\mathrm{d}_{4}$ is not prone to spontaneous coal combustion; it is not prone to methane outbursts from the floor but dangerous in coal-dust explosions. The longwall is within the part of a mine field being prone to coal and gas outbursts. Maximum water inflow within the area is $10 \mathrm{~m}^{3} /$ hour. Seam $\mathrm{d}_{4}$ is mainly of simple structure. Geological thickness of the seam varies within the range of 1.25 up to $1.75 \mathrm{~m}$; average thickness throughout the pillar is $1.47 \mathrm{~m}$. Coal grade is "Forge". Seam occurrence is of low-dipping mode; dip angle is $3-40$.

All the zones of geological disturbances are characterized by high degree of fracturing and instability of the enclosing rocks as well as increased methane content. Spacing of periodic roof caving is $10-15 \mathrm{~m}$; as for immediate roof, it is $1-2 \mathrm{~m}$.

According to the data by exploratory wells, natural gasbearing capacity of the coal seam is $8.8-16.3 \mathrm{~m}^{3} /$ t.d.a.-f.m. Accompanying bed $\mathrm{d}_{4}{ }^{1}$ with the thickness of $0.10-0.30 \mathrm{~m}$ occurring within the roof at the distance of $17.70-18.05 \mathrm{~m}$ is a potentially dangerous source of methane emission. Moreover, methane may be emitted from sandstones occurring in the floor and roof of the seam with natural gas-bearing capacity being $0.15-6.9 \mathrm{~m}^{3} / \mathrm{m}^{3}$ of the rock.

The longwall is ventilated in terms of return-flow ventilation scheme of $1-\mathrm{M}-\mathrm{N}-\mathrm{v}-\mathrm{vt}$ type; calculated air consumption is $Q_{\text {calc }}=1569 \mathrm{~m}^{3} / \mathrm{min}$ while actual one is $Q_{\text {fact }}=1814 \mathrm{~m}^{3} / \mathrm{min}$. Degassing of accompanying beds by means of underground wells is used as additional measure to control methane. Two types of degassing pipelines with the diameters of 325 and $426 \mathrm{~mm}$ were used. Methane is released from the worked-out area through the isolated channel (pipeline) with the help of gas-suction fan of VMTsH-7M type.

The $13^{\text {th }}$ southern and $14^{\text {th }}$ southern belt entry are driven along the coal seam involving coal-cutting with the enclosing rocks and roof layer. Type of frame support is KShPU-17.7; spacing of support mounting is $0.8 \mathrm{~m}$. Roof and walls are lagged with cyclone fencing. 
Mining method is represented by long-pillar $(1732 \mathrm{~m})$ working along the strike; stoping lengths are $300 \mathrm{~m}$. The roof is controlled by complete caving. Length of stoping face is $290 \mathrm{~m}$. The $14^{\text {th }}$ southern longwall is equipped with CZK-260/852 conveyor, 1DT support, SP-202 beam conveyor, and JOY7LS20 shearer. Shearer operation is of shuttle type. Average extracted thickness of coal seam is $1.47 \mathrm{~m}$. Minimum area of cross-section of the stop face area is $3.6 \mathrm{~m}^{2}$.

\section{RESULTS AND DISCUSSION}

Observations in terms of both mines have demonstrated that air flows entering the ventilation districts did not contain carbon oxide during the monitoring period.

Carbon oxide was detected in August 5, 2014 in air drift of "Pioner" mine (point 1, Fig. 2); that was considered as the prerequisite for coal self-heating. Although, in terms of slow stoping rates as well as considerable areas of exposed surfaces of easily oxidizable coal of the seam and interlayer, minor volumetric shares of carbon oxide in the mine air was not yet to be a sign of the beginning of a self-heating process. There were no possibilities to measure temperature in coal accumulations rela- tive to unsaturated hydrocarbons (Pashkovskiy, 2013). Production operations were stopped for safety reasons.

A decision was taken to intensify the control of mine air composition and (when the composition is stabilized) to provide intense stoping advance with simultaneous intensification of unsupported share of air drift of the $3^{\text {rd }}$ northern longwall. To reduce air leakage into the worked-out area of the longwall, curtains were erected throughout the longwall within the length of $20 \mathrm{~m}$ from belt entry and within the length of $60 \mathrm{~m}$ from air drift. Isolation of the unsupported share of air drift was reinforced with additional betonite and cut log stoppings and soil mortar poured between them. Content of carbon oxide was reduced down to the admissible limits being $0.0001-0.0014 \%$.

After the beginning of stoping operations (08.08.2014), short-duration exceed in oxygen consumption up to $20.59 \mathrm{l} / \mathrm{min}$ was recorded in mine workings before the midday of 09.08.2014; further the excess was not more than 4-6 1/min (Fig. 5). Air consumption of $441 / \mathrm{min}$ was recorded in the air removed from the worked-out area $V_{\mathrm{CO}}$ with the help of a degassing plant. Later, the consumption was $10-12 \mathrm{l} / \mathrm{mine}$ being observed up to 12.08 .2014 ; then, it was not more than $61 / \mathrm{min}$.



Figure 5. Dynamics of carbon oxide emission (I/min) within the control stations of the $3^{\text {rd }}$ northern longwall of m ${ }^{2}$ seam of $500 \mathrm{~m}$ level: 1 - air drift $20 \mathrm{~m}$ from the longwall hole; 2 - mouth of the air drift; 3 - in a degassing pipeline

The results of observations demonstrate the adequacy of the operating decisions made by the emergency management. As a result, preventive measures to reduce fire hazards and maintain normal air composition within the control stations have been completed successfully. Evaluation of the situation within the test area involving European methodology shows that the TG content in the mine working air was within the limits of $10<V_{\text {co }} \leq 251 / \mathrm{min}$ and $\mathrm{CO}$ level was not more than $0.0017 \%$, i.e. $\Delta \mathrm{CO} \leq 0.0026$. The situation was not beyond the scope of stage one (Trenchek, 2017) stipulating intensification of the measures to control TG emission and implementation of preventive measures.

Figure 6 demonstrates the output per stoping face $A$, $\mathrm{t} /$ day, and CO emission, $1 / \mathrm{min}$, in terms of "Pokrovske" mine office.
Results of the analysis of air samples taken within the control stations have shown that no considerable fluctuations of $\mathrm{CO}$ content within the degassing pipelines and the channel of isolated gas-air mixture removal were observed. At the same time, in terms of the mouth of the $13^{\text {th }}$ southern belt entry (station 1 ), tracer gas consumption $V_{\text {co }}$ varied from 0 up to $6 \mathrm{l} / \mathrm{min}$, and $\Delta \mathrm{CO}$ content was much higher than the permissible level of $0.0017 \%$. That allows concluding on the fact that there is no generation of tracer gases within the mass of enclosing rocks. As it is known, CO generation requires oxygen contained in a ventilation flow and coal, a material prone to oxidizing. Air in the depth of worked-out areas is diluted with methane, oxygen content is reduces; that decelerated oxidizing processes, therefore, $V_{\text {co }}$ consumption is low (station 2). 


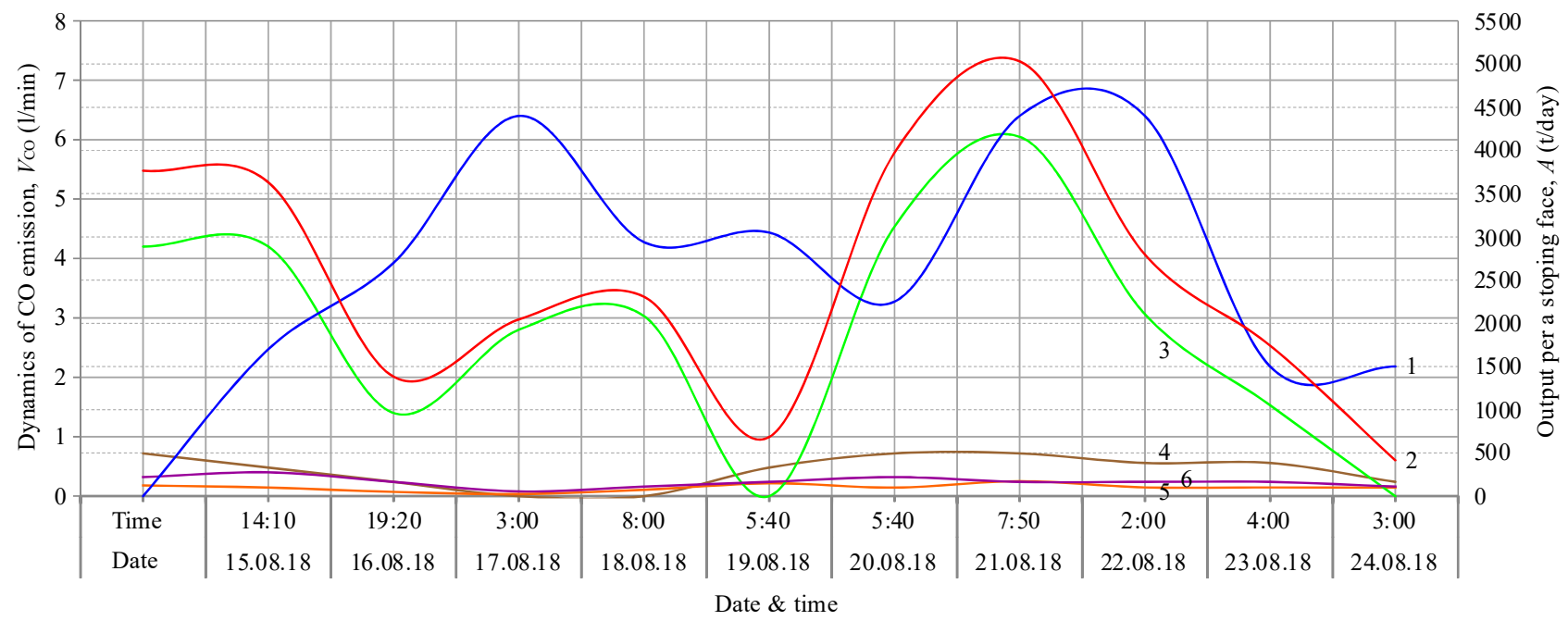

Figure 6. Graph of changes in the output per stoping face A, t/day (1) and dynamics of CO emission, l/mine total (2) as well as in terms of control stations of the $14^{\text {th }}$ southern longwall of block 10 of "Pokrovske" mine office: 3 - the $13^{\text {th }}$ southern belt entry, the area outgoing; 4 - pipeline of the isolated methane removal VMTsH-7M; 5, 6-degassing pipelines of 0426 and $0325 \mathrm{~mm}$

Fluctuations in TG consumption within the airremoving mine working are characterized by certain periodicity. In this content, peaks of $V_{\text {co }}$ index coincide approximately with the ones of the stoping face output ( $A, \mathrm{t} /$ day). Maximum $V_{\text {co }}$ values in the $13^{\text {th }}$ southern entry interchange with the periods of its complete nonavailability. Minimums on the graph of $\mathrm{CO}$ dynamics recur with constant periodicity of $3-6$ days (e.g. August 19 and 24, 2018). That has made it possible to assume the formation of certain TG share as a result of mechanical coal destruction by mining machines.
Specified daily output is preset as $A_{\max }=5846 \mathrm{t} /$ day, actual average output per face in terms of 10 days of observation is $2821 \mathrm{t} /$ day, and total output per 10 days is $31040 \mathrm{t}$. During the observation period, daily output per face varied from 1500 up to 4600 t/day.

Analyze dependences of $\mathrm{CO}$ and $\mathrm{CH}_{4}$ gas emissions during mining operations involving a statistic method to identify the available correlation between two processes. Figure 7 represents graph of changes in output per a stoping face and dynamics of $\mathrm{CH}_{4}$ emission, $\mathrm{m}^{3} / \mathrm{min}$ under the same conditions and stations of gas sampling.

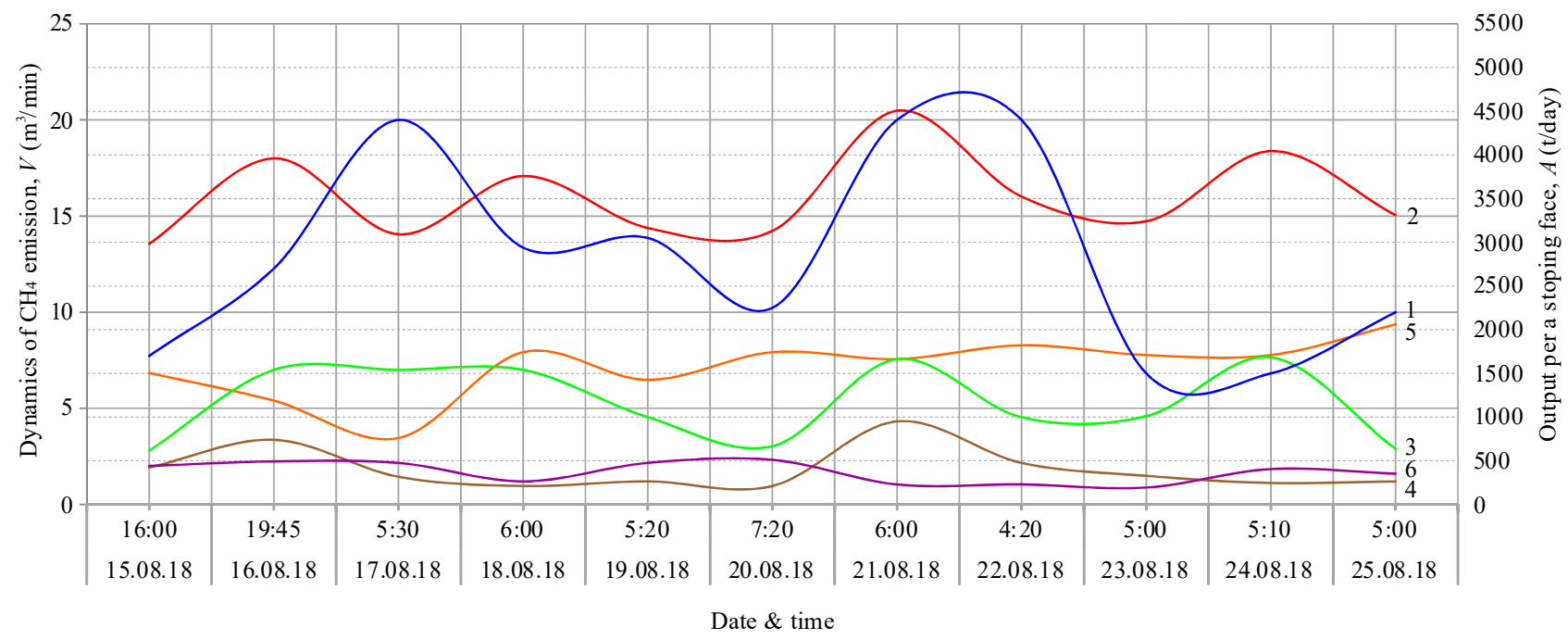

Figure 7. Graph of changes in output per a stoping face $\mathrm{A}, \mathrm{t} /$ day (1) and dynamics of $\mathrm{CH}_{4}$ emission, $\mathrm{m}^{3} / \mathrm{min}$ total (2) as well as within the control stations of the $14^{\text {th }}$ southern longwall of block 10 of "Pokrovske" mine office: 3 -the $13^{\text {th }}$ southern belt entry, the longwall outgoing; 4 -pipeline of the isolated methane removal VMTsH-7M; 5, 6-degassing pipelines of 0426 and $0325 \mathrm{~mm}$

Gas emission level did not go down to a zero one; it fluctuated within the range of $14-20 / \mathrm{min}$. In this context, methane consumption in the $13^{\text {th }}$ belt entry (station 1) corresponded rather clearly to the level of coal output; extraction peaks coincide with the peaks of methane emission. The same tendency is observed in the pipeline of isolated methane removal (station 2). In terms of wells, level of methane emission is quasi-constant. The results make it possible to confirm the known data on the fact that there is certain constant methane emission from the rock mass; in terms of the considered case, it is $12-14 \mathrm{~m}^{3} / \mathrm{min}$. It is overlapped by additional gas flow stipulated my methane liberation while coal seam mining and its periodical forcing out from the worked- 
out area during caving of the immediate floor and subsidence of the main floor. Difference in $\mathrm{CO}$ and $\mathrm{CH}_{4}$ dynamics demonstrate different mechanisms of their origin and emission into the mine workings (Kostenko, Zavyalova, \& Kostenko, 2016). Coefficients of correlation $(0.083-0.406)$ between their emission indices indicate weak connection between those processes.

Subsidence of the main floor is the most probable activator which forces carbon oxide, being accumulated within the stagnant sites of the worked-out areas, away from the mine workings. That is confirmed by pulsed and relatively regular character of its entering into the outgoing line of the $14^{\text {th }}$ southern longwall (Fig. 7) and roof caving that accompanies the displacement of the $3^{\text {rd }}$ northern longwall (Fig. 3). That is the basis to draw conclusions on inexpediency of TG indices control $\left(V_{\mathrm{co}}\right.$ and $\triangle \mathrm{CO}$ ) while intensifying mining operation rates or during the main roof subsidence. To exclude the disturbances connected with the mechanical destruction of coal, air sampling to control coal self-heating should be performed in several hours after the termination of coal getting from the seam, e.g. not earlier than the middle of maintenance shift.

One should remember that the observations cover only two stoping areas mined in terms of pillar system with return-flow ventilation onto the mass. The obtained results are not numerous; they need further confirmation and clarification. The studies are expedient to carry out in terms of other mining-geological and mining-technical conditions of the development of coal deposits in Ukraine.

It is recommended to get approval from the bodies of mining and sanitary inspection as for the short-term increase of carbon oxide content level, admissible in mine workings, up to the one of $0.0026 \%$, provided that there are all the required safety measures. That will help ensure safe intense displacement of longwalls from the selfheating places with the intensified measures of air composition control and isolation of the worked-out area as well as avoidance of the development of endogenous fire.

\section{CONCLUSIONS}

In terms of current Ukrainian coal deficiency due to military conflict, possible underground accidents deteriorate considerably energy situation in the country. The situation is also complicated by the fact that Ukrainian mines have no means to prevent and detect early stages of the most common and complex type of underground accidents - fires caused by spontaneous coal combustion.

It is expedient to adapt European practices for Ukrainian mines as for the monitoring of atmosphere composition within the production units and dynamics of tracer gases to detect early stages of coal self-heating. Ukrainian coal industry is equipped with the means required for that implementation. Complexity of the adaptation is in the considerable difference between the standards of air safety at working places.

Two Ukrainian mines have been tested experimentally to check the approach to a routine control of coal selfheating basing upon the dynamics of tracer gases in terms of pillar mining with return-flow air supply to a ventilation district. It has been determined that within the area of an assumed coal self-heating place, $\mathrm{CO}$ consump- tion in mine workings reaches $20.59 \mathrm{l} / \mathrm{min}$. Worked-out area was the source of trace gases emission. If there were no signs of self-heating, then $\mathrm{CO}$ consumption was not more than $4-61 / \mathrm{min}$.

Intense coal extraction results in the increased TG emission. In terms of "Pokrovske" mine office, observations demonstrated grown $\mathrm{CO}$ emission (from 2.5 up to $61 / \mathrm{min}$ ) along with the increased output per a stoping face (from 1500 up to $4600 \mathrm{t} /$ day). If mining operations were stopped, carbon oxide was almost constant; fluctuations are consistent with the measurement error.

The results demonstrate that formation of tracer gases characterizing self-heating level within coal accumulations are effected greatly by geological (coal grade, seam occurrence, seam disturbance) and technological (development system, ventilation scheme, advance rate of stoping operations, downtime etc.) factors. Importance of each of those factors requires further specification.

Conclusion may be drawn on the applicability of European methodology to predict coal self-heating in the context of both considered and other mining and technical conditions of Ukrainian mines. In this context, one should stipulate the possibility of short-term deviation from the safety rules as for getting permission to perform mining operations at $\mathrm{CO}=0.0026 \%$.

\section{ACKNOWLEDGEMENTS}

We express our gratitude to the authorities of the State Militarized Mining Rescue Service of the Ministry of Energy and Coal Industry of Ukraine for the possibility to use materials of gas-and-air surveying during our studies.

\section{REFERENCES}

Feng, X., \& Adamus, A. (2014). Overview of research and use of indicator gases of coal spontaneous combustion in China. GeoScience Engineering, 60(1), 55-65. https://doi.org/10.2478/gse-2014-0006

Hu, X., Yang, S., Zhou, X., Yu, Z., \& Hu, C. (2015). Coal spontaneous combustion prediction in gob using chaos analysis on gas indicators from upper tunnel. Journal of Natural Gas Science and Engineering, (26), 461-469. https://doi.org/10.1016/j.jngse.2015.06.047

Kostenko, V.K., Zavyalova, Ye.L., \& Kostenko, T.V. (2016). Protsessy samonagrevaniya $i$ vozgoraniya uglya $v$ shakhtakh. Saarbrücken, Germany: LAP LAMBERT Academic Publishing.

Kronbauer, M.A., Izquierdo, M., Dai, S., Waanders, F.B., Wagner, N.J., Mastalerz, M., \& Silva, L.F.O. (2013). Geochemistry of ultra-fine and nano-compounds in coal gasification ashes: a synoptic view. Science of the Total Environment, (456-457), 95-103. https://doi.org/10.1016/j.scitotenv.2013.02.066

Martinello, K., Oliveira, M.L.S., Molossi, F.A., Ramos, C.G., Teixeira, E.C., Kautzmann, R.M., \& Silva, L.F. O. (2014). Direct identification of hazardous elements in ultra-fine and nanominerals from coal fly ash produced during diesel cofiring. Science of the Total Environment, (470-471), 444-452. https://doi.org/10.1016/j.scitotenv.2013.10.007

NPAOP 10.0-1.01-10. (2010). Pravila bezopasnosti v ugolnykh shakhtakh. (2010). Kyiv, Ukraina: Ministerstvo Yustytsii Ukrainy.

Oliveira, M.L.S., Ward, C.R., Izquierdo, M., Sampaio, C.H., de Brum, I.A.S., Kautzmann, R.M., \& Silva, L.F.O. (2012). Chemical composition and minerals in pyrite ash of an 
abandoned sulphuric acid production plant. Science of the Total Environment, (430), 34-47. https://doi.org/10.1016/j.scitotenv.2012.04.046

OSHA Method ID-210. (1991). Carbon monoxide in workplace atmospheres. Salt Lake City, United States: Salt Lake Technical Center.

Pashkovskiy, P.S. (2013). Endogennye pozhary $v$ ugolnykh shakhtakh. Donetsk, Ukraina: Znannia.

Regulation of the Minister of Energy of 16 March 2017 on emergency rescue. (2017). Journal of Laws, Item 1052.

Ribeiro, J., Taffarel, S.R., Sampaio, C.H., Flores, D., \& Silva, L.F.O. (2013). Mineral speciation and fate of some hazardous contaminants in coal waste pile from anthracite mining in Portugal. International Journal of Coal Geology, (109-110), 15-23.

https://doi.org/10.1016/j.coal.2013.01.007

Rukovodstvo po preduprezhdeniyu $i$ tusheniyu endogennykh pozharov na ugolnykh shakhtakh Ukrainy. (2000). Donetsk, Ukraina: NIIGD "Respirator".

Rukovodstvo po proektirovaniyu ventiliatsii ugolnykh shakht. (1994). Kyiv, Ukraina: Osnova.
Stracher, G.B., \& Taylor, T.P. (2004). Coal fires burning out of control around the world: thermodynamic recipe for environmental catastrophe. International Journal of Coal Geo$\log y, 59(1-2), 7-17$. https://doi.org/10.1016/j.coal.2003.03.002

Trenchek, S. (2017). Assessment of methane and spontaneous fire hazards level in the areas ventilated by refreshment of returned air in light of the applicable regulations. Katowice, $(10,21-28$.

Yashchenko, I.A. (2017). Shakhtery soobshchayut SOS. Nauchno-Proizvodstvennyi Zhurnal "Okhrana Truda", (7), 5-7.

Zhu, H., Chang, M., \& Wang, H. (2017). Study on primal CO gas generation and emission of coal seam. International Journal of Mining Science and Technology, 27(6), 973-979. https://doi.org/10.1016/j.ijmst.2017.06.002

Zhuang, L., \& Ji-Ren, W. (2011). The technology of forecasting and predicting the hidden danger of underground coal spontaneous combustion. Procedia Engineering, (26), 2301-2305.

https://doi.org/10.1016/j.proeng.2011.11.2438

\section{ЗАСТОСУВАННЯ ЄВРОПЕЙСЬКОГО ПІДХОДУ ДО ПРОГНОЗУ САМОНАГРІВАННЯ ВУГІЛЛЯ НА ШАХТАХ УКРАЇНИ}

\section{Ю. Гамій, Я. Ляшок, В. Костенко, О. Зав’ялова, Т. Костенко, О. Костирка}

Мета. Прогноз самонагрівання вугілля і визначення факторів, які впливають на динаміку виділення індикаторних газів (ГГ), що використовуються для поточного контролю самонагрівання вугілля на видобувній дільниці, шляхом застосування європейського підходу.

Методика. Для визначення вмісту шахтних вентиляційних потоків рудничної атмосфери відбиралося в резинові камери об'ємом 1 літр, після чого у газоаналітичній лабораторії Державної воєнізованої гірничорятувальної служби (ДВГРС) за допомогою газоаналізаторів “Сигма-СО-В”, “Кристал” визначали вміст газів (\%). Розташування точок відбору газових проб обрано у відповідності до нормативних документів. Періодичність відбору проб при виявленні загрози самонагрівання вугілля у виробленому просторі складала кожні 3 години, у звичайному режимі - не менше 1 разу на добу. Період спостереження на виїмкових дільницях - не менше 9 - 10 діб. Експериментальні спостереження виконані на виїмковій дільниці шахти “Піонер” та шахтоуправління “Покровське”.

Результати. Виконано перевірку нового підходу до поточного контролю самонагрівання вугілля 3 урахуванням динаміки IГ, при стовповій системі розробки зі зворотноструминним провітрюванням дільниці. Встановлено, що в районі передбачуваного осередку самонагрівання вугілля витрата СО у виробках досягала 20.59 л/хв, а джерелом виділення ІГ був вироблений простір; при відсутності ознак самонагрівання - витрата не перевищувала $4-6$ л/хв. Встановлено, що інтенсивне виймання вугілля призводить до збільшення виділення IГ. Так, зі збільшенням навантаження на очисний вибій від 1500 до 4600 т/добу зростає виділення СО від 2.5 до 6.0 л/хв. Визначено, що на характер виділення ІГ ключову роль відіграють геологічні (марка вугілля, залягання пласта і його порушеність) та технологічні (система розробки, схема провітрювання, швидкість посування очисних робіт, тривалість простоїв та ін.) фактори.

Наукова новизна. Вперше для гірничо-геологічних і гірничотехнічних умов Донбасу встановлено фактори, що визначають динаміку індикаторних газів на видобувній дільниці при стовповій системі розробки пласта.

Практична значимість. Обгрунтована та доведена можливість використання європейської методики поточного контролю самонагрівання вугілля на українських шахтах.

Ключові слова: ендогенна пожежа, самонагрівання вугілля, індикаторні гази, вентиляційний потік, термодеструкція вугілля

\section{ПРИМЕНЕНИЕ ЕВРОПЕЙСКОГО ПОДХОДА К ПРОГНОЗУ САМОНАГРЕВАНИЯ УГЛЯ НА ШАХТАХ УКРАИНЫ}

\section{Ю. Гамий, Я. Ляшок, В. Костенко, Е. Завьялова, Т. Костенко, О. Костырка}

Цель. Прогноз самонагревания угля и определение факторов, влияющих на динамику выделения индикаторных газов (ИГ), используемых для текущего контроля самонагревания угля на добычном участке, посредством применения европейского подхода.

Методика. Для определения состава шахтных вентиляционных потоков рудничный воздух отбирался в резиновые камеры объемом 1 литр, после чего в газоаналитической лаборатории Государственной военизированной горноспасательной службы (ГВГСС) с помощью газоанализаторов “Сигма-СО-В”, “Кристалл” определяли содержание газов (\%). Расположение точек отбора газовых проб выбрано в соответствии с нормативным документом. Периодичность отбора проб при выявлении угрозы самонагревания угля в выработанном пространстве составляла каждые 3 часа, в обычной обстановке - не реже 1 раза в сутки. Период наблюдения на выемочных 
участках - не менее 9-10 суток. Экспериментальные наблюдения выполнены на выемочном участке шахты "Пионер" и шахтоуправлении "Покровское".

Результаты. Выполнена проверка нового подхода к текущему контролю самонагревания угля с учетом динамики ИГ, при столбовой системе разработки с возвратноточным проветриванием участка. Установлено, что в районе предполагаемого очага самонагревания угля расход СО в выработках достигал 20.59 л/мин, а источником выделения ИГ являлось выработанное пространство; при отсутствии признаков самонагревания - расход не превышал 4-6 л/мин. Установлено, что интенсивная выемка угля приводит к увеличению выделения ИГ. Так, с увеличением нагрузки на очистной забой от 1500 до 4600 т/сут возрастает выделение СО от 2.5 до 6.0 л/мин. Определено, что на характер выделения ИГ ключевую роль играют геологические (марка угля, залегание пласта и его нарушенность) и технологические (система разработки, схема проветривания, скорость подвигания очистных работ, длительность простоев и др.) факторы.

Научная новизна. Впервые для горно-геологических и горнотехнических условий Донбасса установлены факторы, определяющие динамику индикаторных газов на добычном участке при столбовой системе разработки пласта.

Практическая значимость. Обоснована и подтверждена возможность использования европейской методики текущего контроля самонагревания угля на украинских шахтах.

Ключевые слова: эндогенный пожар, самонагревание угля, индикаторные газы, вентиляционный поток, термодеструкиия угля

\section{ARTICLE INFO}

Received: 30 September 2018

Accepted: 13 February 2019

Available online: 26 February 2019

\section{ABOUT AUTHORS}

Yuriy Gamiy, Engineer of the State Militarized Mine-Rescue Service, 1 Robochyi Ln, 85323, Myrnohrad, Ukraine. E-mail: gamiyyv@gmail.com

Yaroslav Liashok, Doctor of Economic Sciences, Rector of the Donetsk National Technical University, 2 Shybankova Ave., 85300, Pokrovsk, Ukraine. E-mail: iaroslav.liashok@donntu.edu.ua

Viktor Kostenko, Doctor of Technical Sciences, Head of the Department of Environmental Activities, Donetsk National Technical University, 2 Shybankova Ave., 85300, Pokrovsk, Ukraine. E-mail: vk.kostenko@gmail.com

Olena Zavialova, Candidate of Technical Sciences, Associate Professor of the Department of Environmental Activities, Donetsk National Technical University, 2 Shybankova Ave., 85300, Pokrovsk, Ukraine. E-mail: elenazavialova@rambler.ru

Tetiana Kostenko, Candidate of Technical Sciences, Professor of the Department of Construction Objects Safety and Labor Protection, Cherkasy Institute of Fire Safety named after Chornobyl Heroes of National University of Civil Defense of Ukraine, 8 Onopriienko St, 18034, Cherkasy, Ukraine. E-mail: tatiana.kostenko@gmail.com

Olesia Kostyrka, Candidate of Technical Sciences, Assistant Professor of the Department of Automatic Safety Systems and Electrical Installations, Cherkasy Institute of Fire Safety named after Chornobyl Heroes of National University of Civil Defense of Ukraine, 8 Onopriienko St, 18034, Cherkasy, Ukraine. E-mail: olesiakostyrka@ukr.net 